\title{
Communicative Approach and Spoken English Teaching of Independent Colleges \\ Shuo Yang
}

\author{
School of Foreign Languages, Jinlin Business and Technology College,ChangChun,130507
}

Key words: spoken English teaching of independent colleges; current situation of spoken English learning; communicative approach

\begin{abstract}
Communication is the ultimate purpose of language learning. Spoken English is playing a more and more important role in English teaching. The students of independent colleges have a certain degree of particularity, thus teachers should pay more attention to the teaching strategies of spoken English. This article studies the current situation of spoken English leaning in independent college and analyzes the impacts and guiding effects of communicative approach on spoken English teaching.
\end{abstract}

\section{Introduction}

Along with the increasingly frequent international communications in economy and culture, China' s requirement on the English speaking ability of high-level talents is increasingly high ${ }^{[1-2]}$. The Ministry of Education states implicitly in the Curriculum Requirements on College English Teaching that the students must be trained for their comprehensive English abilities, especially listening and speaking. Therefore, it is very important to train the students, practical communicative ability in the college English teaching ${ }^{[3-6]}$. In particular, it deserves further discussion and research on the application of communicative method which aims at actual communication in the improvement of the students' speaking ability in the independent colleges where students' English level is relatively low.

\section{Communicative Method}

The communicative method is proposed by the sociolinguist Hymes regarding Chomsky' s "language competence" . According to On Communicative Competence by Hymes published in 1971, the learner' s language competence is not only the making of sentences in conformity with grammar, but also the appropriateness of the sentences. It means that the language learner must know the appropriate way to talk efficiently with different persons in different circumstances. Hymes' communicative competence theory emphasizes the context of the conversation. His theory becomes an important theoretical foundation for communicative method. After Hymes proposes the concept of “communicative competence" , Canale \& Swain extends it to Grammar competence, sociolinguistic competence, discourse competence and strategic competence which are the abilities to be trained for the learners in class according to communicative method. It is suggested by British functional linguist Firth and Halliday, American sociolinguist John Gumper and William Labov that not only the language structure but also the linguistic competence and communicative competence shall be trained for the language learners. These are all theoretical foundations for the proposal of communicative method. Other important driving force for the proposal of communicative method is the founding of European Community in the 1970s. Linguists concentrate on the study of language teaching method in order to break the language barriers among the western European countries. Communicative English Teaching by Widdowson published in 1978 becomes the foundation for the rapid development of communicative method in 1970s.

In the late 1970s, communicative method is introduced into China by Candlin and $\mathrm{Hu}$ Wenzhong. After that, it is further researched by Sun $\mathrm{Li}$ and Xin Bin. Since then, the communicative method has been widely applied in China' s colleges, and primary and middle schools. 


\section{Current Situation of Spoken Language Teaching in Independent Colleges}

\section{A.Lack of motivation, and poor basic language competence}

The students in independent colleges lack of learning motivation. They failed to achieve better scores in the college entrance examination, mostly because they don' t like study, but not because they have intellective problems. Teachers should pay special attention to the inspiration of the students' interests in the independent colleges, and teach with a clear target. Students of independent colleges are generally poor in Basic English, and can' t speak English fluently. They did not lay a solid foundation of the foreign language in middle school, and wasted that period of time when they had the best comprehension and memory. In addition, the English teaching in middle school is typically the impartment of knowledge in written form, using the Grammar-translation method, and neglects the training of the students' communicative ability. The weakness of the students' Basic English knowledge affects their speaking ability. B.Influence of the traditional teaching mode on the college English teaching

Although the teaching concept and method of college English are very different from that of middle school, and have been constantly reformed over the past decade, the traditional teaching mode that regards highly on reading and writing and makes light of listening and speaking still roots in people' s minds. In most classes, the teachers are the imparters and the students are passive listeners. The classroom atmosphere is boring, teachers explaining a great amount of vocabulary and translating the texts, with few activities for the students. The students in independent colleges who are poorly motivated and autonomic are less interested, and don' t want talk. In this way, their speaking ability can never be trained or improved.

\section{C.Fear and avoidance of speaking}

Because of the independent college students' low level of English and weakness in oral expression, they are generally afraid and reluctant of speaking due to a sense of inferiority. In a teacher-centered class, it makes them nervous and anxious when the teacher and other students are speaking English. In turn, this nervousness and anxiety take a negative effect on the students' oral expression so that they make mistakes that could have been avoided. If the teacher frequently reminds and corrects their mistakes, the students' frustration will be further aggravated. The frustration will make the students never want to speak English again. Since the improvement of speaking ability requires constant practices, this vicious cycle does a lot of harm. The students need a relaxing environment to practice their oral English.

D.Few opportunities in the class for oral practices

Since most colleges don not provide dedicated oral lessons for non-English majors, the teachers must organically combine oral English with Intensive Reading Course and Listening Course, and add oral practices into the general English class. Moreover, in typical large-size classes of college English mostly containing 40-60 students, the teachers must figure out the way to practice and improve the students' oral English as much as possible.

\section{Specific Application of Communicative Method in teaching Oral English in Independent Colleges}

The teaching activities shall be benefit for the training of the students' language-applied communicative competence, on the basis of the social demand and the teaching program for college English required by the Ministry of Education. Based on the use of language, regarding the teaching process as a communication process, the communicative method provides a situated context for language learning, for the purpose of communication. Therefore, the proper application of the communicative method in the teaching of college oral English is very beneficial. The communicative method has not been clearly defined, while according to linguists Widdowson, Breen \& Candlin, and Savignon, and Appied Linguistics by Angelis \& Henderson published in 1989, the method' s characteristics can be summarized and applied in the teaching of oral English 
in independent colleges as follows:

A.The objective of language teaching is to train the students' communicative ability, but not to be limited on the impartment of grammar or linguistic knowledge

Language is a tool for communication. The traditional learning of grammar and vocabulary is only a step to achieve communication, but not all. In language teaching in accordance with communicative method, the teachers should get rid of the bondage of the traditional grammar-translation method, and should not limit on the impartment of vocabulary and grammar. Nevertheless, in the classroom activities, teachers should create specific language situations for the students to actively participate in, such as teacher-student or student-student Q\&A, role play, group work and speeches. Note that the students in independent colleges are poor in Basic English, so the language application must be combined with the teaching of basic grammar, in order to truly improve the students' oral expression. Thus, the teachers should figure out the proper proportion of grammar teaching and oral practice in a class, and flexibly exert the teaching strategies. For the design of oral practice, the distinctive characteristics of the independent college students must be considered. For example, before a conversation practice, some related typical sentence patterns may be taught, and a certain amount of time should be provided for the students to prepare.

B.The teaching activity should be student-centered and teacher-assisted

In a class, the students are the center, while the teacher is just an organizer and supervisor. The teacher should abandon the traditional teaching mode in which the teacher alone has the say and is a leader. The leading role of a teacher is mainly embodied in the impartment of basic knowledge such as grammar. But this impartment should not be redundant; once the knowledge is understood by the students, they should be given the opportunity to practice. The teacher should also be an organizer to choose appropriate topics and methods to create a relaxing atmosphere for the students to learn, and guide them to proactively join in the communication activities. The materials and topics chosen ought to be interesting for the students taught. Although independent college students have a weak foundation of study, they are active thinkers with extensive social contacts. As long as they are interested in the topics, they will want to speak. Once their communicative motivation is inspired, they will participate in the communication activities and become the center of the teaching activity. C.Oral fluency precedes over grammar correctness of spoken language

From the perspective of communicative method, in the communication process, the fluency of language precedes over the correctness of grammar. That is to say mistakes are unavoidable while the students are speaking English. The communicative method encourages students to freely communicate. Teachers need not interrupt and correct the students' mistakes, in order to maintain the fluency of the students' spoken language. Especially for the students in independent colleges who are poor in Basic English and feel too inferior to speak English, it will damage the students' sense of confidence and pride if the teacher frequently interrupt them and correct their mistakes. If so, the students will not want to speak English again because they want to avoid making mistakes, and there will be no communication. Therefore, it is even more necessary to create a relaxing atmosphere for the students of independent colleges. The students' oral mistakes could be temporarily "ignored" and not immediately pointed out. The mistakes may be explained in the final summary of the class or be implied in later classes. Note that the language fluency must not injure the expression clarity. The grammar mistakes may be ignored, but the meaning must not be unclear.

D.The students should be allowed to creatively use the language in a non-rehearsal situation

In a class applying communicative method, the design of classroom activities should be specifically purposive and operable. The activities should be similar with the students' daily life. The students should be allowed to creatively and acceptably use the language in a non-rehearsal situation. This is difficult to some extent for teachers who teach a non-mother language, but could be assisted by using some teaching techniques such as movies, videos, tapes and computer software. 


\section{Conclusion}

In theory, the teaching of college English ought to be an extension in listening, speaking, reading and writing on the basis of the basic knowledge taught in middle school. But in practice, the improvement of speaking ability needs more effort of the teachers and students in independent colleges where the students are poor in basic language skill. As the guiders for English learning, the teachers should transform their teaching concepts, and combine basic grammar knowledge with communicative activities, in order to motivate the students' communicative potential, in such a way that the speaking ability of independent college students will be improved.

\section{References}

[1] KONG Fanli. Application of Communicative Method to Improve Students’ Speaking Ability [J]. China Science and Technology Information, 2006(02):102-103

[2] QIN Zhiquan, WANG Dingquan. Understanding and Implementing the Communicative Method in College Spoken English [J]. 2009(147):71-72

[3] FENG Lianyi, WU Lei. Brief Investigation on College Spoken English [J]. 2005(02):24-32

[4] CHEN Haiyan. Application of Communicative Method in Teaching College Spoken English [J]. 2007(03):119-120

[5] SONG Min, DI Xiaona. On Reform of English Teaching at Vocational Colleges. Examination Weekly [J]. 2012.56:7-8

[6] HU Qin, CHEN Fang. Application of Communicative Method in Integrated Course of College English. Overseas English [J]. 2015.03:21-23 